\title{
UJI SELEKTIVITAS ALAT TANGKAP GILLNET MILLENIUM TERHADAP HASIL TANGKAPAN IKAN KEMBUNG (RASTRELINGER BRACHYSOMA)
}

\author{
Alinda Putri Anggreini*), Septiana Sri Astuti, Irfan Miftahudin, \\ Putri Inova Novita, Dewa Gede Raka Wiadnya
}

Fakultas Perikanan dan Ilmu Kelautan, Universitas Brawijaya

\begin{abstract}
Abstrak
Keputusan Menteri No.2 2015 telah melarang semua trawl dan pukat tarik. Untuk mengimbangi kerugian tersebut, Kementerian Kelautan dan Perikanan mengeluarkan jaring insang millenium (3,5 inci) dan memberikannya untuk nelayan. Penelitian ini bertujuan untuk mengevaluasi selektivitas alat tangkap jaring insang millenium yang diluncurkan, yang menargetkan ikan kembung (Rastrelliger brachysoma) dalam hasil tangkapannya. Penelitian dilakukan di Selat Madura, dengan membandingkan jaring insang millennium dengan jaring insang biasa (2,0 inci). Hasilnya menunjukkan kedua alat tangkap tersebut memiliki kategori panjang yang sama $(18,28 \pm 0,707951$ untuk jaring insang millenium, dan 18,78 \pm 0,92655 untuk jaring insang biasa). Semua ikan kembung (Rastrelliger brachysoma) yang tertangkap ditemukan pada tahap kematangan penuh (tingkat kematangan III atau IV). Jaring insang umum menghasilkan biomassa tangkapan yang jauh lebih tinggi daripada jaring milenium (632 ekor), dikarenakan ukuran jaring yang lebih kecil. Jadi, kedua alat tangkap tersebut dianggap selektif untuk menangkap ikan kembung. Agar dapat diterima, diperlukan pengurangan ukuran jaring untuk jaring insang millenium.
\end{abstract}

Kata kunci : Gillnet millenium, selektivitas, kematangan gonad.

\section{PENDAHULUAN}

Indonesia adalah salah satu negara dengan jumlah spesies ikan tertinggi di dunia. Banyaknya jenis dan jumlah spesies ikan menimbulkan masalah tersendiri di bidang penangkapan. Banyaknya spesies ikan membutuhkan berbagai alat tangkap yang harus digunakan sebagai sarana penanangkapan ikan.

Permasalahan yang lain adalah digunakannya alat tangkap yang tidak ramah lingkungan. Hal tersebut mendorong pemerintah untuk melakukan pelarangan penggunaan alat tangkap yang tidak ramah lingkungan yang memberikan dampak negatif terhadap keberlanjutan sumberdaya ikan. Salah satu peraturan yang dikeluarkan adalah Peraturan Menteri Kelautan dan Perikanan RI Nomor 2 Tahun 2015 mengenai pelarangan penggunaan alat tangkap pukat tarik dan pukat hela.

Peraturan pemerintah mengenai pelarangan penggunaan pukat tarik dan pukat hela memberikan dampak hilangnya pekerjaan khususnya untuk nelayan karena sebagian besar nelayan Indonesia menggunakan alat tangkap pukat hela dan pukat tarik sebagai sarana penangkapan ikan. Selain itu peraturan menteri tersebut berimbas pada turunnya jumlah produksi, di Jawa Timur produksi perikanan menurun sebesar 29\%. Saat ini diperlukan jalan keluar untuk menangani permasalahan tersebut.

Salah satu yang disinyalir sebagai jalan keluarnya adalah dengan mengganti pukat hela dan pukat tarik dengan gillnet millenium. Gillnet millenium adalah terobosan alat tangkap yang dinilai ramah lingkungan dan menghasilkan hasil tangkapan lebih banyak dari gillnet biasa. Oleh karena itu alat ini dicanangkan sebagai sarana penangkapan ikan dan mampu menjawab segala permasalahan tersebut. Gillnet millenium sendiri

* Anggreini. Tel: +62-85246986621

E-mail: randani56@gmail.com

(C) 2017 at http://jfmr.ub.ac.id 
sebenarnya telah di salurkan oleh pemerintah ke beberapa daerah namun pada kenyataannya banyak sekali nelayan yang belum menggunakan alat tangkap gillnet millennium tersebut dengan alasan alat tangkap yang tidak dapat menghasilkan tangkapan yang maksimal untuk nelayan.

Gillnet millenium merupakan jenis alat tangkap gillnet yang telah dimodifikasi dari gillnet pada umumnya, perbedaanya terdapat pada bahan jaring yang memiliki serat pilinan multimonofilament serta warna jaringnya yang bening atau transparan. Gillnet biasa dibuat dari bahan nylon multifilament berwarna biru gelap, sementara gillnet millennium dibuat dari nylon multimonofilament yang transparan. Jaring multi monofilament umumnya menggunakan bahan yang tipis, sehingga jaring lebih halus dibandingkan dengan jaring monofilament atau jaring multifilament. Hal itu membuat jaring multi monofilament lebih fleksibel di bawah air[1].

Operasi penangkapan ikan oleh setiap jenis alat tangkap memiliki perbedaan. Hal ini dikarenakan setiap jenis alat tangkap memiliki kontruksi yang berbeda yang disesuaikan dengan tujuan hasil tangkapan dan kondisi perairan pada daerah penangkapan ikan. Perbaikan dan modifikasi konstruksi alat tangkap telah banyak dilakukan untuk keberhasilan operasi penangkapan. Salah satu alat tangkap yang melakukan pengembangan kontruksi adalah jaring millenium (gillnet millenium). Jaring millenium ini merupakan jenis alat tangkap yang serupa dengan jaring insang (gillnet), namun memiliki perbedaan dengan jaring insang (gillnet) pada umumnya. Perbedaan tersebut yaitu terdapat pada bahan jaring yang memiliki serat pilinan multimonofilament, jenis hasil tangkapannya serta proses pengoperasiannya pada perairan yang dalam[ 2]. Jaring gillnet millennium memiliki serat yang tidak terpilin atau biasa disebut dengan ply. Gillnet millennium yang biasa digunakan biasanya teridir dari 4 ply, 6 ply, 8 ply hingga 10 ply. Dengan serat yang terbuka ini ikan lebih mudah tersangkut di jaring karena ply akan terbuka di dalam air. Selain itu gillnet millennium lebih kuat jika terkena arus, karena terdiri dari beberapa serat benang.

Kontruksi adalah jaring millenium (gillnet millenium). Jaring millenium ini merupakan jenis alat tangkap yang serupa dengan jaring insang (gillnet), namun memiliki perbedaan insang (gillnet), namun memiliki perbedaan dengan jaring insang (gillnet) pada umumnya. Perbedaan tersebut yaitu terdapat pada bahan jaring yang memiliki serat pilinan multimonofilament, jenis hasil tangkapannya serta proses pengoperasiannya pada perairan yang dalam[2]. Jaring gillnet millennium memiliki serat yang tidak terpilin atau biasa disebut dengan ply. Gillnet millennium yang biasa digunakan biasanya teridir dari 4 ply, 6 ply, 8 ply hingga 10 ply. Dengan serat yang terbuka ini ikan lebih mudah tersangkut di jaring karena ply akan terbuka di dalam air. Selain itu gillnet millennium lebih kuat jika terkena arus, karena terdiri dari beberapa serat benang.

Alat ini dinilai dapat digunakan sebagai alat tangkap yang ramah lingkungan dan dapat meningkatkan hasil tangkapan. Alat tangkap yang baik adalah alat tangkap yang memiliki sifat ramah lingkungan dan selektif. Selektif adalah sifat alat tangkap yang mampu menangkap ikan pada ukuran tertentu dan yang telah melalui matang gonad pertama kali. Hal tersebut sangat penting untuk diketahui untuk mengetahui keramahan dan selektifitas dari alat tangkap tersebut.

Ikan kembung merupakan ikan pelagis kecil yang memiliki nilai ekonomis menengah, sehingga terhitung sebagai komoditas yang cukup penting bagi nelayan lokal. Ikan kembung (Rastrelliger brachysoma) merupakan jenis ikan ekonomis penting, umumnya tersebar di perairan pantai (zona neritik) dan merupakan komoditi utama pada perikanan rakyat. Kegiatan penangkapan yang dilakukan secara intensif dari tahun ke tahun menyebabkan jumlahnya semakin berkurang. [3].

\section{METODE}

Penelitian uji selektivitas alat tangkap gillnet millennium dilaksanakan di Desa Jatirejo, Kecamatan Lekok, Kabupaten Pasuruan pada bulan Maret - Mei 2017. Sedangkan untuk analisis penelitian dilakukan di Laboratorium Sumberdaya Ikan, Fakultas Perikanan dan Ilmu Kelautan, Universitas Brawijaya Malang.

Metode yang digunakan didalam penelitian ini adalah Experimental Fishing yaitu metode penelitian dengan menggunakan sampel objek penelitian yang tertangkap pada alat tangkap 
untuk diamati. Didalam penelitian ini dilakukan penyeleksian nelayan sebagai tahap pengumpulan informasi dengan wawancara untuk mendapatkan informasi yang dibutuhkan. Untuk menguji selektivitas alat tangkap, pengukuran gillnet millenium dilakukan untuk data sebagai analisa selanjutnya.

Alat yang digunakan dalam penelitian ini adalah gillnet millenium nelayan, yang digunakan untuk menangkap ikan kembung, left jacket, coolbox, freezer. Sedangkan bahan yang digunakan dalam penelitian ini adalah ikan kembung hasil tangkapan nelayan yang menggunakan gillnet millenium. Selain itu, bahan lain yang digunakan dalam analisis penelitian mengenai selektivitas gillnet millenium adalah formalin $10 \%$, botol film, kertas label dan penggaris ukur

\subsection{Rancangan Penelitian}

Dalam pelaksanaan penelitian terbagi dalam beberapa tahap antara lain:

\subsubsection{Seleksi Nelayan}

Pada tahap pertama dalam penelitian ini yang dilakukan adalah penyeleksian nelayan, dalam tahap ini berisi kegiatan wawancara dan pengumpulan informasi mengenai alat tangkap gillnet millennium agar tercapainya kesepakatan dalam kerjasama penelitian ini.

\subsubsection{Identifikasi Alat Tangkap}

Dalam hal ini kami mengukur mesh size gillnet millennium untuk digunakan sebagai data dalam analisa selanjutnya. Pada penelitian ini digunakan dua jenis gillnet sebagai pembanding. Gillnet pertama yang digunakan adalah gillnet millennium dengan ukuran mesh size 3,5-4 inchi dan yang kedua adalah gillnet biasa dengan ukuran mesh size 2 inchi. Identifikasi ini dilakukan untuk mengetahui hanging ratio alat tangkap menggunakan formula :

Keterangan :

$$
E=\frac{L}{L_{\mathrm{o}}}
$$

$\mathrm{E}=$ Hanging ratio

$\mathrm{L}=$ Panjang jaring sesudah terpasang

$\mathrm{L}_{\mathrm{o}}=$ Panjang jaring sebelum terpasang

\subsubsection{Melaksanakan operasi penangkapan ikan bersama nelayan}

Pada kegiatan penangkapan ini, kami terjun langsung dilapang bersama nelayan untuk mengetahui hasil tangkapan yang di dapatkan menggunakan gillnet millennium khususnya ikan kembung. Dalam penelitian dilakukan 3 kali pengulangan pada masingmasing gillnet.. Satu kali ulangan adalah satu kali kegiatan operasi penangkapan (settinghauling).

\subsubsection{Mengamati cara tertangkapnya ikan kembung}

Pada saat proses hauling (penarikan alat tangkap) dilanjutkan dengan pengamatan dan pengumpulan data cara tertangkapnya ikan secara gilled dan non-gilled (snagged, wedged, dan entangled). Kondisi tertangkapnya ikan dianalisis berdasarkan proporsi dari masingmasing kategori (snagged, gilled, wedged dan entangled).

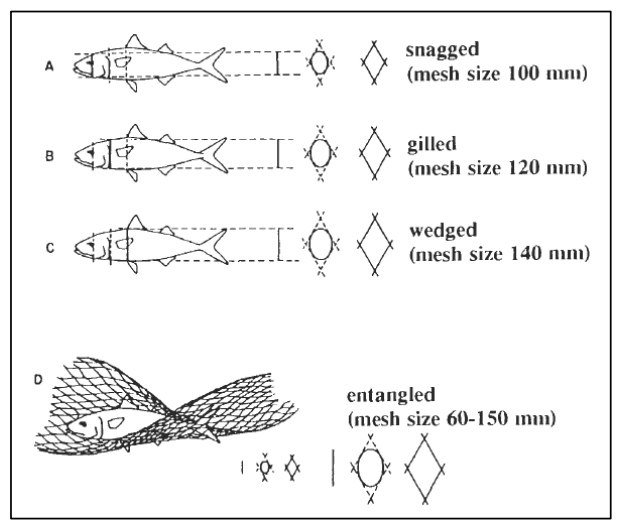

Gambar 1. Cara Tertangkapnya Ikan pada Gillnet (Sumber : Sparre dan Venema, 1998)

\subsubsection{Mengukur panjang dan tingkat kematangan gonad}

Dalam mengukur panjang dilakukan dengan pengukuran FL (fork length) yaitu pengukuran dimulai dari mulut hingga cagak ekor. Setelah itu kami melakukan pembedahan, dan kemudian data yang didapatkan disajikan dalam analisis deskriptif menggunakan grafik dan nilai panjang rata-rata ikan yang paling banyak tertangkap untuk mengetahui tingkat kematangan gonad ikan.

Setelah menganalisis dari semua data yang telah dikumpulkan, apabila panjang ikan yang paling banyak tertangkap (Lc) kurang dari panjang ikan yang matang gonad pertama kali (Lm) maka dapat disimpulkan alat tangkap tersebut tidak selective dan sebaliknya. 


\subsubsection{Analisis Data}

Analisis uji selektivitas alat tangkap gillnet millennium yaitu melakukan pengumpulan data panjang yang selanjutnya dimasukkan kedalam selang kelas yang telah ditentukan, kemudian memasukkan frekuensi masing-masing kelas sehingga akan didapatkan rata-rata panjang ikan yang paling banyak tertangkap yaitu Lc. Data dianalisis dengan menggunakan formula selektivitas gillnet Spare and Venema.[4].

$$
S(L) m=\exp \left(-\frac{L-L m^{2}}{2 S^{2}}\right)
$$

Keterangan :

$$
\begin{array}{ll}
\mathrm{S}(\mathrm{L}) \mathrm{m}= & \begin{array}{l}
\text { peluang ikan dengan panjang } \mathrm{L} \text { yang } \\
\text { tertangkap pada gillnet dengan ukuran } \\
\text { mata jarring }
\end{array} \\
\mathrm{Lm}=\begin{array}{l}
\text { Fork length ikan efektif yang } \\
\text { tertangkap oleh ukuran mata jaring m }
\end{array} \\
\mathrm{L}=\begin{array}{l}
\text { Fork length ikan yang tertangkap oleh } \\
\text { gillnet ukuran mata jaring m }
\end{array} \\
\mathrm{L}= & \text { standar deviasi kurva seletivitas }
\end{array}
$$

Selanjutnya dilakukan pengukuran tingkat kematangan gonad dengan metode Histologi. Hasil dari tingkat kematangan gonad tersebut digunakan untuk mengetahui panjang ikan yang sudah matang gonad pertama kali yaitu Lm. Setelah mengetahui panjang ikan matang gonad pertama kali maka dilakukan dengan analisis data panjang untuk mengetahui selektifitas dari alat tangkap tersebut.

\section{HASIL DAN PEMBAHASAN}

Penelitian ini bertujuan untuk mengetahui selektivitas dari alat tangkap gillnet millenium. Parameter uji utama penelitian ini adalah tingkat kematangan gonad dari ikan kembung (Rastrelinger brachisoma) yang duji secara histologis.

\section{a. Identifikasi alat tangkap}

Hanging ratio adalah persentase dari panjang jaring yang terpasang pada tali ris dibagi dengan panjang jaring yang direntangkan secara sempurna (panjang jaring sebelum dibuat alat tangkap).[5] Identifikasi yang kami lakukan didapatkan gillnet millennium memiliki ukuran mesh size sebesar 3,5 inchi dan memiliki hanging ratio sebesar 0,59 . Jaring insang biasa memiliki ukuran mesh size 2 inchi dan memiliki nilai hanging ratio sebesar 0,55. Berdasarkan hasil tersebut dapat disimpulkan bahwa gillnet millennium dan gillnet biasa cenderung menjerat ikan dan lebih selektif. Hal ini sesuai dengan pendapat Fachrudin dan Hudring yang menyatakan hanging ratio horizontal pada gillnet umumnya 0,5. Hanging ratio lebih kecil dari 0,5 jaring cenderung memuntal ikan dan akan menangkap berbagai spesies ikan yang berbeda.[5] Sebaliknya jika hanging ratio lebih besar 0,5, maka jaring cenderung menjerat ikan dan lebih selektif dibandingkan dengan jaring di atas, hal ini sering terjadi pada jaring insang hanyut.

\section{b. Mengikuti Kegiatan Nelayan}

Mengikuti kegiatan nelayan ini dimaksudkan untuk mengetahui pengoperasian alat tangkap gillnet millennium, dari proses setting, drifting hingga hauling. Kemudian untuk mengetahui cara tertangkapnya ikan, dari mengikuti kegiatan nelayan yang menggunakan alat tangkap gillnet millennium kebanyakan ikan tertangkap di bagian mulut (snagged) dan di bagian sirip dorsal (entangled). Pada gillnet biasa ikan banyak tertangkap di insang (gilled).

Tabel 1.

Hasil Tangkapan Gillnet Millenium

\begin{tabular}{lc}
\hline \multicolumn{1}{c}{ Jenis Ikan } & Jumlah (ekor) \\
\hline Kuro & 75 \\
Baracuda & 10 \\
Rajungan Merah & 9 \\
Layang & 5 \\
Layur & 15 \\
Bawal & 15 \\
Kembung & 48 \\
\hline \multicolumn{1}{c}{ Jumlah } & $\mathbf{1 7 7}$ \\
\hline
\end{tabular}

Tabel 2.

Hasil Tangkapan Gillnet Biasa

\begin{tabular}{lc}
\hline \multicolumn{1}{c}{ Jenis Ikan } & Jumlah (ekor) \\
\hline Kuro & 6 \\
Baracuda & 5 \\
Layang & 2 \\
Kurisi & 2 \\
Layur & 3 \\
Peperek & 232 \\
Buntal & 1 \\
Sotong & 1 \\
Lidah & 1 \\
Udang & 5 \\
Ikan Lemadang & 8 \\
Kembung & 366 \\
\hline \multicolumn{1}{c}{ Jumlah } & $\mathbf{6 3 2}$ \\
\hline
\end{tabular}




\section{c. Hasil Pembedahan Ikan}

Ikan kembung yang didapatkan dari nelayan, selanjutnya dibawa ke laboratorium untuk dibedah, pengukuran panjang dan berat ikan. Pembedahan ini dilakukan untuk mengetahui TKG (Tingkat Kematangan Gonad) ikan kembung dan mengetahui jenis kelamin ikan kembung. Hasilnya adalah semua ikan kembung yang ditangkap menggunakan gillnet millennium dan gillnet biasa telah matang gonad tingkat III dan tingkat IV.

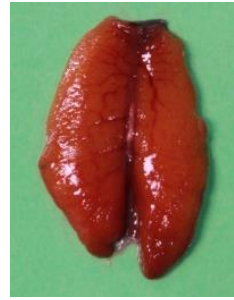

(a)

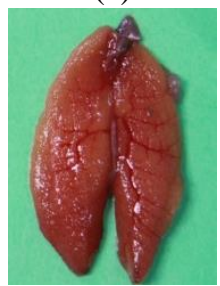

(c)

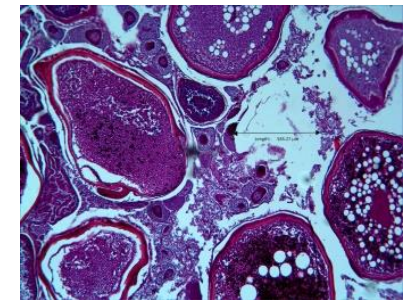

(b)

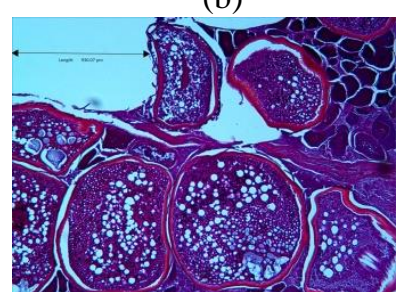

(d)
Gambar 2. (a) Gonad Ikan Kembung Kematangan Tingkat III; (b) Hasil Histologi Gonad Ikan Kembung Kematangan Tingkat III; (c) Gonad Ikan Kembung kematangan Tingkat IV; (d) Hasil Histologi Gonad Ikan Kembung Tingkat IV

\section{d. Pengujian Selektivitas}

Semakin sedikit jumlah hasil tangkapan yang tertangkap secara entangled, kemungkinan besar alat tangkap tersebut selektif. Jumlah atau proporsi ikan yang tertangkap dengan gillnet secara entangled sangat menentukan selektivitas dari alat tangkap gillnet sehingga penting untuk mengetahui proporsi hasil tangkapan dan cara tertangkapnya ikan pada hasil tangkapan.[4].

Tabel 3.

Kisaran dan Rata-rata fork leght yang tertangkap

\begin{tabular}{lccc}
\hline \multicolumn{4}{c}{ Fork Length } \\
$\begin{array}{c}\text { Alat } \\
\text { Tangkap }\end{array}$ & $\begin{array}{c}\text { Ukuran } \\
\text { Kisaran }(\mathbf{C m})\end{array}$ & $\begin{array}{c}\text { Modus } \\
(\mathbf{C m})\end{array}$ & $\begin{array}{c}\text { Rata-Rata } \\
(\mathbf{C m})\end{array}$ \\
\hline Gillnet & $16,25-$ & 18,28 & 17,73 \\
Millenium & 19,05 & & \\
Gillnet & $16,01-$ & 18,78 & 17,09 \\
Biasa & 20,35 & & \\
\hline
\end{tabular}

Tabel 4.

Kisaran dan rata-rata berat ikan kembung yang tertangkaap

\begin{tabular}{lccc}
\hline \multicolumn{4}{c}{ Berat } \\
Alat & $\begin{array}{c}\text { Berat } \\
\text { Kisaran } \\
(\mathbf{g r})\end{array}$ & $\begin{array}{c}\text { Modus } \\
(\text { gr })\end{array}$ & $\begin{array}{c}\text { Rata-Rata } \\
(\text { gr) }\end{array}$ \\
\hline $\begin{array}{l}\text { Gillnet } \\
\text { Millenium }\end{array}$ & $46-104$ & 79 & 77,67 \\
GillnetBiasa & $42-95$ & 70 & 67,72 \\
\hline
\end{tabular}

Dalam experimental fishing diketahui bahwa ikan kembung (Rastrelliger brachysoma) banyak tertangkap dengan cara gilled. Hal ini sesuai dengan cara tertangkapnya ikan yaitu secara gilled, wedged dan entangled. Berdasarkan hasil penelitian, proporsi ikan yang tertangkap secara gilled pada gillnet millenium adalah sebesar $10 \%$ sedangkan untuk gillnet biasa adalah sebesar $90 \%$.

Kondisi tertangkap ikan amat bergantung pada ukuran dan pemberontakan ikan melepaskan diri dari jeratan. Pada ikan berukuran kecil dimana keliling tubuhnya lebih fleksibel terhadap keliling mata jaring, mereka dapat memasukkan kepalanya ke mata jaring namun akan terjerat secara snagged atau gilled. Sementara itu, pada ikan berukuran sedang atau besar dengan keliling tubuh lebih besar daripada keliling mata jaring, kemungkinan terpuntal lebih besar akibat pemberontakan untuk melepaskan diri.[6]

Untuk menentukan selektivitas dari gillnet milleniium, dilakukan analisis untuk melihat $\mathrm{Lm}$ atau $\mathrm{L}_{50}$ pada hasil tangkapan. $\mathrm{L}_{50}$ adalah panjang ikan yang mempunyai peluang tertangkap sebesar $50 \% . \quad \mathrm{L}_{50}$ ini biasanya digunakan sebagai kriteria untuk menentukan penggunaan mata jaring. Analisis faktor ukuran mata jaring juga dapat menunjukan pengaruhnya terhadap jumlah hasil tangkapan dan ukuran ikan hasil tangkapan.

Dalam pengujian selektivitas didapatkan Lm pada gillnet millennium (panjang ikan yang pertama kali matang gonad) adalah $18.275 \mathrm{~cm}$ dan pada gillnet biasa $18.775 \mathrm{~cm}$. Selanjutnya adalah melakukan perhitungan untuk mengetahui panjang Lc (Length Catch), pada gillnet millenium didapatkan Lc sebesar $18.275 \mathrm{~cm}$ dan pada gillnet biasa sebesar $18.275 \mathrm{~cm}$ 


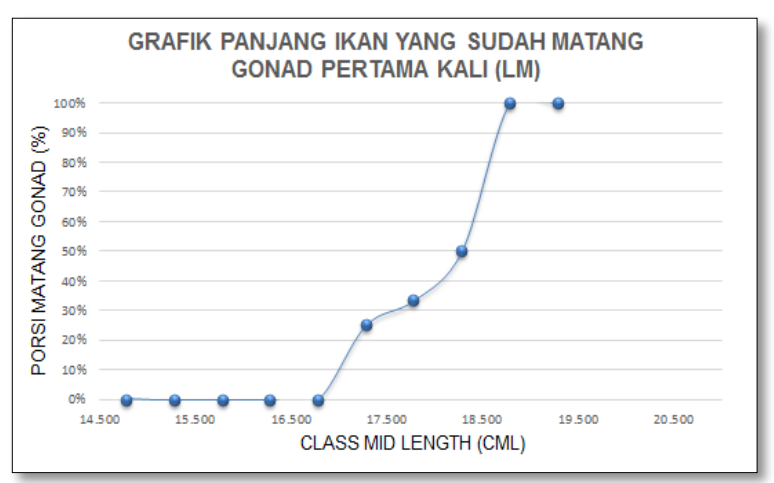

Gambar 3. Grafik Distribusi Panjang Ikan Kembung Matang dan Tidak Matang Gonad Pada Gillnet Millenium

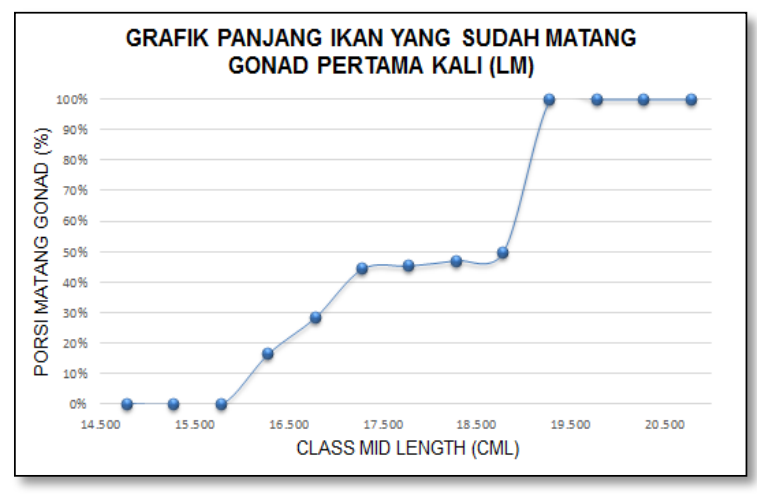

Gambar 4. Grafik Distribusi Panjang Ikan Kembung Matang dan Tidak Matang Gonad pada Gillnet Biasa

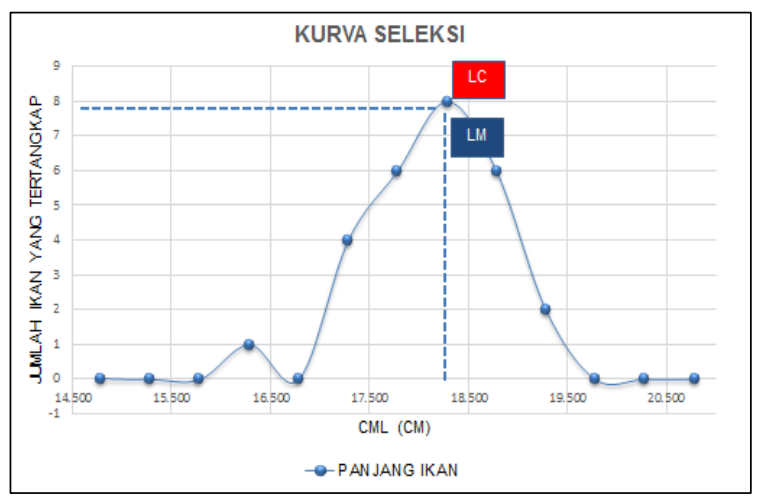

Gambar 5. Grafik Hasil Analisis Lc dan Lm pada Gillnet milleniu

\section{KESIMPULAN}

Dari penelitian yang telah dilakukan, didapatkan kesimpulan bahwa gillnet millenium adalah alat tangkap yang selektif. Berdasarkan hasil analisis, gillnet biasa adalah alat tangkap yang kurang selektif. Gillnet millenium dengan Lc $(18,275)$ dan Lm $(18,275)$. Berdasarkan hasil tersebut, dapat dilihat bahwa $\mathrm{Lc}=\mathrm{Lm}$ dan dapat disimpulkan bahwa alat tangkap gillnet millenium tersebut selektif. Sedangkan untuk gillnet biasa didapatkan hasil untuk $\operatorname{Lm}(18,775)$ dan Lc $(18,275)$. Berdasarkan hasil tersebut, dapat dilihat bahwa Lc kurang dari Lm dan dapat disimpulkan bahwa alat tangkap gillnet biasa adalah alat tangkap yang selektif.

Alat tangkap gillnet millennium dapat menangkap ikan lebih banyak dibandingkan dengan gillnet biasa, hal ini dikarenakan gillnet millennium memiliki serat yang tidak terpilin sehingga ikan dapat lebih mudah tersangkut di jaring. Gillnet millennium dengan ukuran mesh size 4 inchi kurang cocok digunakan untuk menangkap ikan kembung, hal ini dikarenakan ukuran mesh size yang selektif untuk ikan kembung adalah 1,7 inchi.

\section{UCAPAN TERIMAKASIH}

Alhamdulillah kami panjatkan puji dan syukur kami kepada Allah SWT, karena dengan rahmat dan hidayahnya lah kami dapat menyelesaikan artikel ilmiah penelitian ini. Tak lupa kami ucapkan terimakasih kepada bapak Dr. Ir. Dewa Gede Raka Wiadnya, M.Sc, IPM selaku dosen yang telah membimbing kami dalam penelitian ini. Semoga penelitian ini bermanfaat dan dapat dijadikan referensi pembuatan kebijakan pemerintah dan pembuatan standarisasi alat tangkap gillnet millennium.

\section{REFERENSI}

[1] Diniah. 2011. Gill Net Selektivitas \& Parameter. Temu Ahli Penangkapan Jaring Insang (Gill Net) di WPP Indonesia. Yogyakarta: $14 \mathrm{hlm}$.

[2] Martasuganda, S. 2002. Jaring Insang (Gillnet). Serial Teknologi Penangkapan Ikan Berwawasan Lingkungan. Bogor: Departemen Pemanfaatan Sumberdaya Perikanan.

[3] Suwarso, T. Ernawati dan T. Hariati. 2015. Biologi Reproduksi dan Dugaan Pemijahan Ikan Kembung (Rastrelliger 
brachysoma) di Pantai Utara Jawa. Bawal Vol.7 (1) Hal: 9-16

[4] Sparre, P and Venema, S.C. 1998. Introduction to Tropical Fish Stock Assement. Part/Manual 1. FAO Fisheries Technical Paper. Roma.

[5] Fachrudin dan Hudring. 2014. Identifikasi Jaring Insang (Gillnet). Balai Besar Penangkapan Ikan:Semarang

[6] Haluan, C. C. Rakhmadevi, Ari Purbayanto, dan M. Fedi A. Sondita. 2011. Studi Mengenai Proses Tertangkapnya dan Tingkah Laku Ikan Terhadap Gillnet Millenium Di Perairan Bondet, Cirebon. Marine Fisheries Vol. 3, No. 1: Hal 7-13

[7] KEPMEN KP No. 6/2010. Alat Penangkapan Ikan Di Wilayah Pengelolaan Perikanan Negara Republik Indonesia. Jakarta.

[8] Faife, Jorge Raul. 2003. Effect Of Mesh Size and Twine Type On Gillnet Selectivity Of Cod (Gadus morhua) In Icelandic Coastal Waters. Institute For Development Of Small - Scale Fisheries

[9] Martinus, D. Setyohadi dan A. Syaifudin. Selektivitas Alat Tangkap Gillnet Terhadap Ikan Kembung Perempuan Rastrelliger brachysoma (Bleeker, 1851) Di Perairan Paciran Kabupaten Lamongan, Jawa Timur. Seminar Nasional Perikanan dan Kelautan. Tanggal 8 November 2008, Malang, Indonesia. Halaman 6-11

[10] Suwarso, T. Ernawati dan T. Hariati. 2015. Biologi Reproduksi dan Dugaan Pemijahan Ikan Kembung (Rastrelliger brachysoma) di Pantai Utara Jawa. Bawal Vol.7 (1) Hal: 9-16

[11] Food Agriculture Organization. 2017. The Species Identification and Data Programme.[Online]. http://http://www.fao.org/fishery/

[12] Fridman, A. 1986. Calculation for Fishing Gear Designs. FAO an Agricultur Organisation of The United Nation. Rome. Pages 3-6 